\title{
The Absurd: Postwar Reception and Wartime Echoes at Yale French Studies
}

Julia Elsky

Loyola University Chicago, jelsky@luc.edu

Follow this and additional works at: https://ecommons.luc.edu/modernlang_facpubs

Part of the Modern Languages Commons, and the Modern Literature Commons

\section{Recommended Citation}

Elsky, Julia. The Absurd: Postwar Reception and Wartime Echoes at Yale French Studies. Yale French Studies (Special Double Issue: Existentialism 70 Years After), 135-136, : 46-62, 2020. Retrieved from Loyola eCommons, Modern Languages and Literatures: Faculty Publications and Other Works,

This Article is brought to you for free and open access by the Faculty Publications and Other Works by Department at Loyola eCommons. It has been accepted for inclusion in Modern Languages and Literatures: Faculty Publications and Other Works by an authorized administrator of Loyola eCommons. For more information, please contactecommons@luc.edu. (c) (i) $\Theta$

This work is licensed under a Creative Commons Attribution-Noncommercial-No Derivative Works 3.0 License. (C) Yale French Studies, 2020. 


\section{Yale NUMBERS $135 \& 136$ \\ Existentialism, 70 Years After}

LAUREN DU GRAF, JULIA ELSKY, AND CLÉMENTINE FAURÉ

I. Revisiting and Revising

ALICE KAPLAN 17 ANNE QUINNEY JULIA ELSKY

MARGARET A. SIMONS VICTOR BROMBERT
1 Editors' Preface: The New Lives of Existentialism

31 Marketing Existentialism, 1945-1951

46 The Absurd: Postwar Reception and

Wartime Echoes at Yale French Studies

63 Beauvoir's Long March

75 What Existentialism Meant to Us

II. Between Text and Practice: Existentialism as a Way of Life

FRANÇOIS NOUDELMANN

TORIL MOI
83 Avatars of Existentialism

100 Acknowledging the Other: Reading,

Writing, and Living in The Mandarins

III. Blackness and Existentialism

LEWIS R. GORDON

LAUREN DU GRAF

ROBERT BERNASCONI
119 French- and Francophone-Influenced Africana and Black Existentialism

134 Existentialism's "White Problem": Richard Wright and Jean-Paul Sartre's The Respectful Prostitute

151 Richard Wright as Educator: The Progressive Structure of Simone de Beauvoir's Account of Racial Hatred in the United States

IV. Transnational Circulations: Existentialism and Its Uses

YOAV DI-CAPUA

KATHRYN LACHMAN
171 Arab Existentialism: What Was It?

189 The Meursault Investigation: Literature and the Disappeared

\section{Existentialism and the Religious Question}

SARAH HAMMERSCHLAG CLEMENTINE FAURÉ

BRUNO CHAOUAT
209 Levinas and Sartre: Existentialism after the Stalag 230 "Like a weed on the compost of Catholicity":

Sartre's Self-Division and France's Religious Divide

249 De immundo: Georges Bataille's Gnostic Existentialism 


\section{Yale French Studies}

Lauren Du Graf, Julia Elsky, and Clémentine Fauré

Special editors for this issue

Alyson Waters, Managing editor

Editorial board: Alice Kaplan (Chair), Chandler

Abshire, Morgane Cadieu, Tom Connolly,

Jill Jarvis, Alice Kaplan, Christopher L.

Miller, Pierre Saint-Amand, Anna Salzman,

Maurice Samuels, Christophe Schuwey

Assistant editor: Sophia Helverson

Editorial office: 82-90 Wall Street, Room 308

Mailing address: P.O. Box 208251, New Haven,

Connecticut 06520-8251

Sales and subscription office:

Yale University Press, P.O. Box 209040

Hew Haven,Connecticut 06520-0940

Copyright 2019 by Yale University

All rights reserved.

This book may not be reproduced, in whole or in part, in any form (beyond that copying permitted by Sections 107 and 108 of the U.S. Copyright Law and except by reviewers of the public press), without written permission from the publisher.

Designed by James J. Johnson and set in Trump Medieval Roman by Newgen North America. Printed in the United States of America.

ISSN 044-0078

ISBN for this issue 978-0-300-24266-9 


\section{The Absurd: Postwar Reception and Wartime Echoes at Yale French Studies ${ }^{1}$}

Camus defines the absurd in The Myth of Sisyphus as the realization of the world's irrationality resulting from a "confrontation between the human need and the unreasonable silence of the world." ${ }^{2}$ As Sartre would put it in "The Outsider Explained," the absurd is part of the human condition of being-in-the-world; rather than an entity in man or in the world, "[i]t is nothing less than man's relation to the world." Camus's and Sartre's explanations of the absurd as a condition and confrontation, rather than as an external force, would be received in vastly different ways in the first two decades of Yale French Studies (YFS). Reception of the absurd would become a locus of memory of World War II and the center of discussions about the place of language in this history. The absurd in fact over time comes to be seen as an external force or the state of the world, a world fixed in the Occupation. The absurd itself in these discussions even began to stand in for existentialism as a whole. This article reviews postwar reception of the absurd in America over the course of three volumes of YFS: number 1 (1948), number 16 (1955), and number 23 (1959). Articles in these volumes by three major figures in French Studies from the mid-century through the early aughts, Henri Peyre, Jacques Guicharnaud, and Serge Doubrovsky, deal with the writings of Camus, Sartre,

1. I thank Diana Garvin, Christopher Davis, and Jennifer Row, for their generous comments on this article. I am grateful to Zoe Egelman for her expertise on the Guicharnaud Papers. I am especially grateful to Alice Kaplan for her advice on this projet.

2. Albert Camus, The Myth of Sisyphus: And Other Essays, trans. Justin O'Brien (New York: Knopf, 1983), 28.

3. Jean-Paul Sartre, "The Outsider Explained," Critical Essays: Situations I, trans. Chris Turner, (London: Seagull Books, 2010), 153, 150. Text dated February 1943.

YFS 135/136, Existentialism, 70 Years After, ed. Du Graf, Elsky, and Fauré, 02019 by Yale University. 
and Ionesco at the times when YFS was first introducing existentialism and the theater of the absurd to the American academy. In the very first issue, Peyre's article demonstrates how the specter of Vichy became tied to the absurd. Subsequently, in Guicharnaud's contribution, language and close reading take a central role in confronting the absurd to find meaning in language under the Occupation. However, Doubrovsky's article, the first scholarship on Ionesco in YFS's history, reverses Guicharnaud's approach to language and the absurd. Now we find a trope of criticism of the theater of the absurd that theorizes the meaninglessness of language in an absurd world in the aftermath of World War II. Tracing this reception reveals how the theater of the absurd not only began to be seen as part of existentialism in its earliest reception in America, but furthermore, it reveals how looking at existentialism through the lens of the theater of the absurd actually ended up distorting the teachings of existentialism.

\section{8: COMMUNICATING ANGUISH}

The editor and contributors to the inaugural 1948 volume of YFS introduced existentialism to the American university. ${ }^{4}$ Under the direction of Henri Peyre, chairperson and highly influential figure of the Yale University French Department from 1939 to 1969, and the editorship of Robert Greer Cohn, the journal in its early years aimed to introduce important topics in French literature, politics, and culture to non-specialists. ${ }^{5}$ It was first through French departments, as opposed to philosophy departments, that existentialism was taught in universities and treated seriously in academic journals and publications. ${ }^{6}$ In a letter to Harry Levin on November 17, 1947, Peyre

4. Ann Fulton, Apostles of Sartre: Existentialism in America, 1945-1963 (Evanston, IL: Northwestern University Press, 1999), 22-23. The journal is not the first place to have published on the movement, but the devotion of an entire inaugural issue to the topic announced the importance of the journal for introducing existentialism. Other articles on the movement had appeared in previous years and at the same time. To name just a few, they include Herbert Marcuse's "Existentialism: Remarks on JeanPaul Sartre's L'être et le néant," Phenomenological Research 8/3 (March 1948): 309-36; a three-part series of articles by Marjorie Grene in The Kenyon Review 9/1-3; and Leo Spitzer's article "Man's Need for Faith in Man" in the special section of The American Scholar on "The Humanities Today and Tomorrow" 17/1 (Winter 1947-48): 93-94.

5. Charles A. Porter, "Celebratory Criticism: The First Dozen Years," 50 Years of Yale French Studies: A Commemorative Anthology. Part 1: 1948-1979, Yale French Studies 96 (1999): 13; "Front Matter," Yale French Studies 1, Existentialism (1948), 1.

6. Fulton, Apostles of Sartre, 45. 
boasted that existentialism was "a subject that we have been bold enough to treat here in a graduate course. ${ }^{17}$ Cohn perhaps taught the first course in the United States on existentialism at Yale in $1946 .{ }^{8}$ That same year Sartre visited Yale, preceding Simone de Beauvoir's own tour in the United States. ${ }^{9}$ In the YFS issue, contributors including Peyre and Cohn were preoccupied with defending existentialism against criticism of the movement as a postwar fad that was only popular as a response to the war. Nevertheless, the specter of World War II lurks in many of the articles.

The war's presence in the issue can be felt in the opening articles that provide introductions to the movement. As each maintains that existentialism is not purely related to World War II, the reader senses its presence precisely in the argument of its absence. In "Existentialism-a Literature of Despair?," Peyre writes that it is a disservice to understand the movement "as a mere outgrowth of the Second World War and a reflection of the bad conscience felt by France in 1940 and since." 10 In "French Existentialism before Sartre," Herbert Dieckmann, better known as a Diderot scholar, writing just one year before his death, studies French thinkers who preceded Sartre in order to ground the movement in an intellectually rigorous, interwar French academic milieu. Rather than looking to Kierkegaard, Husserl, Heidegger, and Jaspers, Dieckmann outlines the Recherches philosophiques group that in the 1930s studied these German philosophers, creating "in French a vocabulary for the new mode of thinking." 11 Referring to scholars like Alexandre Koyré, Henri-Charles Puech, and Albert Spaier, Dieckmann adds weight to a movement led by Sartre whom some critics admonish "for having turned Existentialism into a literary fad or having distorted it into a nihilistic and atheistic doctrine." 12 The City University of New York-Brooklyn College Marxist scholar Harry Slochower opens his article, "The Function of Myth in Existentialism," by stating that existentialism is not only a response to the conflicts and choices faced during World

7. Henri Peyre, Henri Peyre: His Life in Letters (New Haven: Yale University Press, 2005!, 241.

8. Fulton, Apostles of Sartre, 23.

9. Annie Cohen-Solal, Sartre: A Life, trans. Anna Cancogni (New York: Pantheon Books, 1987), 273-74.

10. Peyre, "Existentialism-aLiteratureofDespair?" Yale French Studies 1 (1948):28.

11. Dieckmann "French Existentialism before Sartre," Ibid., 34.

12. Ibid., 33. 
War II; it is not only a movement tied to an historic moment, but also one grounded in "absolute categories." Perhaps the war "provides the catalyst for its vogue. But only its catalyst. And only the mood and accent of the movement."13

But what a mood. Despite these statements directed at critics of existentialism, World War II rattles throughout the 1948 issue, either directly or through oblique comments, as if an unavoidable aspect of the philosophy. YFS number 1 opens with an excerpt from Sartre's Dirty Hands, introduced by the editor Robert Greer Cohn who dates the section to just after of the Battle of Stalingrad; Cohn describes the protagonist as "a young bourgeois intellectual, citizen of a certain Eastern European nation which is collaborating with Germany. ${ }^{14}$ Vercors's The Silence of the Sea and its conception under the Occupation is a key example in "The Case for 'Engaged' Literature," Charles G. Whiting's contribution. ${ }^{15}$ Madeleine Smith closes her discussion of The Wall and the character Lucien's involvement in Action-Française by stating that despite the different histories of anti-Semitism and communism in France, Sartre's works still have relevance in American situations. ${ }^{16}$ This brief aside about communism and anti-Semitism seems to refer to recent history in France. And although Slochower, as discussed above, sees World War II as only the catalyst of the movement, he contradicts himself by calling the movement "this German product" that "grew in the soil of the Vichy era."17 Moving from the language of chemistry to biology he sees existentialism as a plant that flourished among those (that is, the French) who were caught between "foreign and native systems"--Nazi Occupation and Vichy rule - "both of which denied their individual existence." 18 Slochower's article demonstrates that, despite all the arguments that date the movement's beginning to much earlier than 1940 or deny its reliance on the war for its importance, the war is an inescapable, almost organic topic of existentialism in this first volume.

Peyre, too, turns to the war, despite his statements arguing that the movement is not only about the war. The Occupation is again

13. Harry Slochower, "The Function of Myth in Existentialism," Ibid., 42.

14. Robert Greer Cohn, introduction to "Scenes from Les mains sales," Ibid., 3

15. Charles G. Whiting, "The Case for 'Engaged' Literature," Ibid., 84-89.

16. Madeleine Smith, "The Making of a Leader," Ibid., 83.

17. Slochower, "The Function of Myth in Existentialism," 50.

18. Ibid. 
the primary historical context for the development of the absurd, as Peyre relies on texts by Camus and Sartre that are explicitly about the war and the immediate postwar period. His primary aim is to demonstrate that existential anguish does not reveal a philosophy of quietism, fear, and inertia. He refers to despair in the article not in the existential sense or in the tradition of Kierkegaard, but rather in terms of the standard definition of losing hope. Existentialist writers for Peyre are not pessimists who ruminate on the negative, nor escapists, nor dilettanti who observe from the outside and get a kind of "Neronian comfort" from the historical disasters in which they live. ${ }^{19}$ He calls existentialist writers "Frenchmen of 1940-48" who have been awoken by the events of the preceding decade to write engaged literature..$^{20}$

To set up his argument that anguish does not lead to inaction, he draws on Camus's article "The Crisis of Man," published in 1946 in Vogue, ${ }^{21}$ in which Camus argues that what Americans might denounce as pessimism among young Frenchmen is actually an awareness of man's condition, which also allows him to strive to overcome it, even if he can never actually do so. ${ }^{22}$ Camus compares this to the necessity to diagnose your disease before being able to treat it. A state of inertia and fear that nothing makes sense comprises a crisis of man. However, because of their experience in the war, young French men and young Europeans have not lived with illusions, have not said that you cannot change man's nature, and instead have faced the harshest realities, that is, the Occupation. Peyre's use of Camus's text inscribes his argument in a political discussion about constructing a postwar order based on the lived experience of World War II.

Sartrean anguish begins to play an important role in Peyre's conception. Sartre distinguishes anguish from fear in part using the example of a soldier at war: fear is when a soldier in artillery preparation is afraid of dying; anguish relates to a change from within, an anxiety a soldier fears about his conduct or even of his being afraid of being

19. Peyre, "Existentialism-a Literature of Despair?," Ibid., 22.

20. Ibid., 23.

21. Although Peyre refers to the article as it appeared in Vogue, it was also published in 1946 in Dorothy Norman's Twice a Year (Fall/Winter 1946-1947): 19-33, in Lionel Abel's translation, directly followed by an article by Harry Slochower on Thomas Mann. I thank Lauren Du Graf for this reference. listed.

22. Albert Camus, "The Crisis of Man," Vogue, July 1, 1946, 86-87. No translator 
afraid. ${ }^{23}$ Yet this anguish is also "the consciousness of freedom,"24 for it contains the realization that one is constantly choosing among possibilities and there is no external validity of these choices. For Peyre the primary questions that existentialists ask in their anguish regard their very existence and the existence of the universe, creating a close link between anguish, freedom, and the absurd. A sense of anxiety grows, writes Peyre, "when they [existentialists] realize that they are a paradox in this irrational universe, where, alone with his reason, man is 'de trop,' unwanted, unfitted, puzzled by the absurdity of his own presence, vainly applying his reason to explain a universe which baffles rationality." 25 This contradiction between the rational individual who is searching for meaning and the irrational world that can offer none is the heart of the absurd.

Nevertheless, rather than true pessimists, escapists, or dilettanti, existential writers are, says Peyre, "metaphysical writers." 26 Peyre is quoting from Sartre's fifth installment of "What is Literature?" in Les temps modernes, ${ }^{27}$ which corresponds to a section of "Situation of the Writer in 1947." For Sartre, metaphysical writers of his period are not concerned with "a sterile discussion of abstract notions" but rather their literature "is a living effort to embrace from within the human condition in its totality." 28 At the end of Being and Nothingness, he had explained his untraditional use of the term metaphysical in relation to "the study of individual processes which have given birth to this world as a concrete and particular totality. ${ }^{29}$ In the wartime context of "Situation of the Writer in 1947," the metaphysical writers focus on praxis, or "action in history and on history," 30 and synthesize both historical relativity and absolute metaphysical morals in a hostile world. A writer does not choose his or her era but chooses how to act in it. For Peyre, this amounts to an austere heroism in the war, when writers did not shy away from their freedom to act.

23. Sartre, Being and Nothingness: An Essay on Phenomenological Ontology, trans. Hazel E. Barnes, (New York: Philosophical Library, 1956), 29.

24. Sartre, Being and Nothingness, 33.

25. Peyre, "Existentialism-a Literature of Despair?," 25.

26. Ibid., 23.

27. Sartre, "Qu'est-ce que la littérature," Les temps modernes (June 1947): $1607-641$.

28. Sartre, What is Literature?, trans. Bernard Frechtman (London: Routledge, 1993), 171.

29. Sartre, Being and Nothingness, 619.

30. Sartre, What is Literature?, 184. 
Writing as a means of acting in history-and not an abstract idea of history-brings the absurd to the fore. Metaphysical writers in What is Literature? create "the literature of great circumstances" precisely in seeing their absurd condition:

Forced by circumstance to discover the pressure of history, as Torricelli discovered atmospheric pressure, and tossed by the cruelty of the time into that forlornness from where we can see our condition as man to the very limit, to the absurd, to the night of unknowingness, we have a task for which we may not be strong enough [ ...] It is to create a literature which unites and reconciles the metaphysical absolute and the relativity of the historical fact $[\ldots]^{31}$

Literature is like Torricelli's barometer, measuring the pressure of history-a history that brings man to the brink in which he sees his condition. Continuing with the language of weather, Sartre describes writers of 1940 as living in a "cyclone" that unhinged the stability of the position of the writer in the interwar period. Now more complex questions emerged, ones that require writers to be "in, by, and for history." 32 "Forlornness" (the original French is "la nuit du non-savoir," and can also be read as abandonment ${ }^{33}$ ), Sartre later states, is the "uncertainty and the risks of the present." ${ }^{134}$ Peyre himself would echo some of these ideas in his 1968 book on Sartre: "For Sartre ..., the absurdity stems from man's realization of his own contingency and of the facticity surrounding him. The world might very well not have been and I too might not have existed. ${ }^{\prime \prime 35}$ The realization of not having chosen your situation, and of that situation not being in any way predetermined yet subject to change, is the realization of the absurd. And this facticity is not abstract but very much linked to the particular historic situation.

Almost a decade later, in his study of The Contemporary French Novel, Peyre writes that if existentialists "delight in pointing out the absurdity of our lives" and "absurdity was rampant in the decade 1940$1950, "$ readers must keep in mind the brutality of the $1940 \mathrm{~s} .{ }^{36}$ That is, anguish in confronting the absurd was drawn out by the historic pres-

31. Ibid., 171.

32. Ibid.

33. Sartre, "Qu'est-ce que la littérature," Les temps modernes : 1630.

34. Sartre, What is Literature?, 172.

35. Peyre, Jean-Paul Sartre (New York: Columbia University Press, 1968), 15.

36. Peyre, The Contemporary French Novel (New York: Oxford University Press, 1955), 220. 
sures of the Occupation and the immediate postwar period. But in his YFS article Peyre does not address the supposed joy of finding the meaninglessness of life, but rather how the existentialists communicated the absurd in writing. In the last section of his article, Peyre speaks of a new form of the novel that emerged and an urgent need to express the historical situation. If existentialist novelists turned to the style of American writers in 1940-1945, it was because it voiced "feelings of men lost and swamped in an immense continent" who are thrown into the incomprehensible conditions of the war. A "brutal means of communication" was necessary to convey the forsakenness of their country, like the forsakenness of Europe as a whole..$^{37}$ But they key here is a desire to convey, a desire to communicate and to act. Communicating the absurd through writing and the relationship between the absurd and language during the war would be a central issue in the reception of the absurd, and a topic that Jacques Guicharnaud began to explore fifteen volumes later in YFS.

\section{5: LANGUAGE IN A HISTORICAL SITUATION}

A new line of thought linked to language and the absurd emerges in Guicharnaud's article "Those Years: Existentialism 1943-1945" in the sixteenth issue of YFS (1955) that was devoted to the theme "Foray Through Existentialism." Guicharnaud was another foundational figure of Yale's French Department, where he taught from 1950 to $1997 .^{38}$ He actually calls his article a testimony, recounting his existentialist awakening as a student in wartime Paris as if it took place many years ago rather than a decade earlier, perhaps in a world that has already passed. His unpublished diaries from those years that he discusses in the article, kept during his late teens and early twenties, provide a parallel account of his coming of age under Vichy and reveal a previously unheard immediate reception of the movement. In these diaries, he makes a rare explicit mention of his view of the Occupation: "There is the war, the Occupation. I never talk about it. Why? One day I will have to say this languor, this uncertainty that weighs on me. ${ }^{39}$ He would

37. Peyre, "Existentialism-a Literature of Despair?," 30.

38. "In Memoriam: Jacques Guicharnaud, French theater scholar and associate of the Existentialists," Yale Bulletin and Calendar 33/22 (March 18, 2005).

39. Beinecke Rare Book \& Manuscript Library, Jacques Guicharnaud Papers, GEN MSS 883, Series II. Writings, Box 4, Folder Notebook: 1943 Mar-1944 Apr, f. 22. Diary entry dated Jan. 12, 1943. 
draw out the philosophical implications of his life under the Occupation in the next decade in his YFS article. In that article, he discusses despair during Occupation years, and also mentions how he came to meet Sartre and Camus toward the end of the Occupation. As he used Sartre's teachings to confront the absurd, Guicharnaud recognized not only that understanding the absurd leads to rebellion and heroism, but also that words had to be understood in their historic situation to be used in meaningful communication of a political point of view.

And here we find a second thread of reception of the absurd: the importance of language itself. When Guicharnaud writes about the time just before he met Sartre, in his prépa studying for the competitive exams to enter the prestigious École normale supérieure, he states that there was no obvious connection at first between the explication de texte exercises he did and the deportation of his friend Levy; the implication after reading the rest of his article is that there is in fact a connection between close reading and his historical situation, but only when the words are historically situated and the absurdity is faced at an intellectual level. This could be read as one explanation of New Criticism, which was in its heyday and whose towering figures René Wellek, Cleanth Brooks, and Robert Penn Warren, were at Yale at the time. New Criticism has been disparaged for just being a form of explication de texte, ${ }^{40}$ but here Guicharnaud proposes historically situated close readings as an alternative, perhaps thereby implicitly criticizing New Criticism. Guicharnaud wrote in his unpublished papers that he was worried about publishing this article for fear it would harm his position at Yale. ${ }^{41}$

Existential despair (as opposed to Peyre's use of the word despair), including in regard to his own speech, was Guicharnaud's way in to existentialism. In "Those Years: Existentialism 1943-1945," he lays out his existential path, in which dealing with the absurd as anchored in the war plays a crucial role. He aptly subtitles this section of the article "The Apprentice Existentialist (1943-44)." We find a kind of a four-step program about how to become a young existentialist in the early 1940s. Step one is despair. This despair neither refers to "spec-

40. René Wellek, A History of Modern Criticism: 1750-1950, vol. 6 (New Haven: Yale University Press, 1986), 144.

41. Beinecke Rare Book \& Manuscript Library, Jacques Guicharnaud Papers, GEN MSS 883, Series II. Writings, Box 4, Folder 6: Notebook 1955-1956, ff. 3-4. Entry undated. 
tacular manifestations of romantic despair" nor bitterness. Rather, for Guicharnaud despair means a kind of "uneasy conscience in connection with little things": "I was bursting with problems. Everything had become important, lighting a cigarette, stirring a cup of coffee, using certain words and intonations. The world had become an immense trap for catching crimes. ${ }^{42}$ Despair as a concept in Sartre refers to the fact that although we live in a Godless world of different possibilities that are never certain and are out of our control, we act according to our own will and according to "the set of probabilities that enable action." ${ }^{43}$ For Sartre, man is nothing but his project, a project undertaken in despair; to leave this work to others would be to ignore despair. Guicharnaud's banal acts, which include his use of language, made in a world of possibilities but devoid of answers, all seem to be weighted in despair.

In his diary entries from the episodes Guicharnaud discusses in his article, he actually describes this moment in the related term of angoisse (anguish) rather than despair. Shortly before meeting Sartre for the first time, and just after his first ever mention of reading Sartre (The Wall), he writes: "Cet entre-deux terrible où il y a, derrière, ce que j'étais et, devant, ce que je serai, c'est-à-dire pour l'instant un néant, en tout cas néantisation future de tout ce que je suis actuellement" (This terrible interval where there is, in back of me, what I was and, in front, what I will be, that is to say for the moment a nothingness, in any case a future nihilation of all that I am right now). ${ }^{44}$ In the context of his coming of age diary, this interval certainly seems to correspond to the intense three-year period of prépa, full of failures, between high school and entering the Grande École. But it also relates to a moment of intellectual growth in which words began to take form as something that could change the world. When Guicharnaud looks back at this time for YFS, he mentions the importance of words, specifically words spoken in the everyday, as quotidian as stirring coffee.

This stage of despair ends when he first meets Sartre. Now we enter step two of the program, when "liberty was the root of the

42. Guicharnaud, "Those Years: Existentialim 1943-1945," trans. Kevin Neilson, Yale French Studies 16 (1955): 134.

43. Sartre, Existentialism Is a Humanism, trans. Carol Macomber (New Haven: Yale University Press, 2007), 34.

44. Beinecke Rare Book \& Manuscript Library, Jacques Guicharnaud Papers, GEN MSS 883, Series II. Writings, Box 4, Folder I, Notebook: 1943 Mar - 1944 Apr, f. 17. Diary entry dated Oct. 5, 1942. 
matter. ${ }^{\prime 45}$ In January 1944, his friend Jean-Bertrand Lefèvre-Pontalis (the same J.B. he addresses at one point in the article) introduced Guicharnaud to Sartre. Sartre gave him a clue to confronting his problems; Guicharnaud writes that he "seemed to say" that "the world is yours," but yours to change. This liberty relates to a new approach to language itself. New words entered into the young existentialist's vocabulary-anguish, Dasein, nothingness, liberty, and commitment. Existentialism provided "great metaphors" that helped his generation understand their situation. ${ }^{46}$ Guicharnaud also began to show his writing to Sartre and Camus in the hopes of publishing short stories. In his diaries, Guicharnaud describes Sartre as "le grand petit M. Sartre" (the great short Mr. Sartre) whose "hantise de l'honnêteté, de la propreté morale en face de lui" (obsession with honesty, with moral rectitude before him) intimidates Guicharnaud so that he can hardly speak and realizes that he should reread Nausea ${ }^{47}$ Later in his journal he refers to Sartre as the "maitre" (master or teacher) and "la gentilesse même" (kindness itself) while Camus--"un grand monsieur brun, assez beau et excessivement sympathique. Mais on sent qu'il est profondément malade (ses yeux, et sa voix extraordinaire et extenuée)" (a tall, dark-haired man, rather handsome and excessively nice. But one senses that he is deeply ill [his eyes, his extraordinary and exhausted voice])—is more severe in his feedback on his writing. ${ }^{48}$ Their generosity comes through in Guicharnaud's 1955 article as well, when he recalls how Sartre, Camus, and Beauvoir read and guided so many young writers, rising above snobbism at the Café du Flore. Sartre passed along Guicharnaud's writing to Camus, who published his short story "Quai de la Gare" in Combat (April 14, 1945), and perhaps also his collection of short stories, Entre chien et loup, (Between Dusk and Dawn) that came out with Gallimard in 1946. The language of existentialism was also one linked to publication, for it was intimately tied to Guicharnaud's literary aspirations.

45. Guicharnaud, "Those Years," 135.

46. Ibid., 132.

47. Beinecke Rare Book \& Manuscript Library, Jacques Guicharnaud Papers, GEN MSS 883, Series II. Writings, Box 4, Folder Notebook: 1943 Mar - 1944 Apr, f. 58. Diary entry dated Jan. 24, 1944.

48. Beinecke Rare Book \& Manuscript Library, Jacques Guicharnaud Papers, GEN MSS 883, Series II. Writings, Box 4, Folder Notebook: 1944 Jan-1945 Jul, pages unnumbered. Entries dated April 14, 1944; May 22, 1944; May 12, 1944. 
In step three, Guicharnaud addresses the absurd head on: "the world ceased to be absurd because we knew it was absurd. ${ }^{149}$ In his 1955 article, like in his 1940s diaries, this absurd relates specifically to his situation in occupied Paris: Food shortages, the disappearances of Jewish friends and friends in the Resistance, the threat of bombardments, the contrast between the broadcasts of the collaborationist Radio Paris and those of the BBC, and even his own behavior. Simply accepting this absurd, writes Guicharnaud in 1955, would lead to "tears and sentimental outings. ${ }^{150}$ Instead, spurred by his existentialist awakening, "the intellectual identification of the absurd leads to rebellion. ${ }^{\prime 51}$ His own diaries demonstrate the trap of accepting the absurd in a sentimental sense. At the end of 1943, Guicharnaud expressed despondency that would lead nowhere, scribbling: "lassitude ... s'en foutre. Cafard, cafard. Même pas le spleen" (lassitude . . . don't give a damn. Doldrums, doldrums. Not even spleen). But he finds JB's suggestion to go to war "absurd." ${ }^{152} \mathrm{He}$ does not even feel a Baudelairean, poetic ill humor, but rather avoids existential despair, thus refusing to act.

Encountering the absurd at an intellectual level leads to step four, which is concerned with language as much as action. Once the absurd is accepted, language becomes part of the revolt. Young existentialists like Guicharnaud gave new meanings to words situated in this historical moment, and in particular the word "hero" (one that Peyre also uses to describe the existentialists). This intellectual acceptance of the absurd historical situation of the Occupation, of his position as a student in Paris during the war, made him aware of how words were linked to a concrete, situated, historical moment: "heroism was not appraised according to its military importance, but placed in a historical situation. If this is not done, communication by means of language remains abstract and illusory." ${ }^{\prime 53}$ Later he would analyze other terms like martyr, patriot, Communist, and fascist along these lines to find their meaning within the context of an absurd historical

49. Guicharnaud, "Those Years," 136.

50. Ibid.

51. Ibid.

52. Beinecke Rare Book \& Manuscript Library, Jacques Guicharnaud Papers, GEN MSS 883, II. Writings, Box 4, Folder Notebook: 1943 Mar - 1944 Apr, f. 55. Diary entry dated Dec. 21, 1943.

53. Guicharnaud, "Those Years," 138. 
situation. Only through this facing of angoisse, and accepting the absurd on an intellectual level, did language become a means of communication. Guicharnaud gives us a window into what Peyre may have meant by existentialists turning to American writers (ones like Faulkner and Steinbeck whom Guicharnaud greatly appreciated) during the war to communicate a brutal historical situation.

\section{9: THE DECOMPOSITION OF LANGUAGE}

Peyre and Guicharnaud deal with topics that would become central to discussions of the theater of the absurd-namely, the role of language and communication in confronting the absurd-in journal volumes that either predate the movement or predate discussions of it. In 1948, Peyre was writing about the absurd a few years before what is considered to be the beginning of the theater of the absurd, the first performance of Eugène Ionesco's Bald Soprano in 1950 and Samuel Beckett's Waiting for Godot in 1953. It would not be until 1959 that the theater of the absurd made its way into YFS, save for one article by Edith Kern on Beckett in a volume entitled Motley: Today's French Theatre (No. 14, 1954). Serge Doubrovksy, known as a scholar of classical theater as well as the creator of the term autofiction, published the first article in YFS on Ionesco, "Ionesco and the Comic of Absurdity," in a volume devoted to Humor (No. 23, 1959). This issue included numerous articles on what we would now consider the theater of the absurd, although the term theater of the $a b$ surd had not yet been coined. That would come in 1960 in an article by Martin Esslin and again in his book in $1961 . .^{54}$ Just as the authors of the 1948 YFS volume were already revising existentialism in the 1940s, Doubrovsky calls Ionesco's plays classics of French theater a mere nine years after the first performance of one of Ionesco's plays. Doubrovsky, like Esslin would one year later, opens a new phrase of reception of the absurd in America as he assimilates this theater into existentialism and the existentialist absurd. However, Doubrovsky changes the approach that Peyre and Guicharnaud took, arguing that Ionesco stages the "decomposition" of language in an absurd world. Now language and the absurd are about meaninglessness and the war. Doubrovsky's reading seems to represent in many ways what Gui- 
charnaud and Peyre wrote against years earlier. That is not to say that Doubrvosky's reading came from ignorance of the wartime situation; he survived the Shoah by living in hiding in France under the Occupation. Nor did he lack a deep understanding of Sartre's words; in a work of autofiction, Le livre brisé, Doubrovsky recalls his close relationship with Sartre and his veneration of Nausea, even discussing Sartre as his "père spirituel" (spiritual father). ${ }^{55}$ Rather, he had a particular, and perhaps personal, reading of the absurd.

Doubrovsky reads Ionesco's absurd through the lens of the existential absurd, tinted with a specifically postwar view of the movement. For Doubrovsky, Ionesco's theater has finally shown that literary expression has caught up with the philosophy of the absurd of the previous twenty years, as expressed by Camus and Sartre. It is an absurd anchored in the wake of World War II, as Ionesco is a writer situated in history who responds to "the agony of his century." 56 When asked directly in an interview in 1966 if he was influenced by the philosophy of the absurd, Ionesco responded that "the notion of the absurd was very much in the air at the time. ${ }^{\prime 57}$ The time he refers to is the postwar period, rather than the war itself. Although Ionesco does not point to any particular texts by Camus and Sartre, he does acquiesce that he was influenced by what he read, and that the authors he read were influenced by the time in which they lived. Ionesco was also very much against Sartre's Marxist politics, and certainly never called himself an existentialist. He had a multifaceted understanding of the absurd that both converges and diverges from existentialism: he uses the absurd to describe what he does not comprehend, yet also his desire to comprehend it. Ionesco calls it "this situation of being here that I cannot recognize as being my situation," as well as "a kind of absurdity that is unreason, contradiction, the expression of my being out of tune with the world." 58 Ionesco himself would distance himself more and more from the movement and from Sartre in particular. But in his article, Doubrovksy reads Ionesco's approach as an elaboration of the existential absurd in the postwar moment.

55. Serge Doubrovksy, Le livre brisé (Paris: Editions Grasset, 1989), 71-79. In this same work of autofiction, Doubrovsky also evokes the traumatic memory of surviving the war.

56. Doubrovsky, "Ionesco and the Comic of Absurdity," Yale French Studies 23 (1959): 3 .

57. Claude Bonnefoy, Conversations with Eugène Ionesco, trans. Jan Dawson (New York: Holt, Reinhart, and Winston, 1970), 122.

58. Ibid., 127. 
Doubrovsky defines Ionesco's absurd as "the absurdity of a world where man is left alone to fill in the void of God, give a name and meaning to things and freely, but unjustifiably, create his own values." 59 According to Doubrovsky, Ionesco creates a comedy of circularity and a comedy of proliferation that illustrate both the desire to fill this void and the unrealizability of that action. The denouements of The Bald Soprano and The Lesson that bring the play back again to the beginning in an endless cycle show the negation of an individual character living in a linear progression. Circularity and proliferation also relate to a kind of "all-pervading presence of things" in Ionesco's theater; Douvrbosky includes examples of this proliferation such as the numerous chairs The Woman sets up for an empty audience in The Chairs, the overproduction of eggs in The Future Is in Eggs, the unending moving in of furniture in The New Tenant, and the ever-growing corpse in Amedée or How to Get Rid of It. Doubrovsky recalls Roquentin's sense of "the essential emptiness of man before the monstrous kingdom of objects" in Nausea. ${ }^{60}$ He points out that anguish comes along with seeing the absurd; for Sartre this is the anguish of man's responsibility. ${ }^{61}$ But Doubrovsky maintains that Ionesco goes further in showing this anguish through evoking an absurd laughter. His theater holds up a mirror to the spectators, in which they see man's disintegration, and where tragedy becomes farce. This is a laughter directed at man rather than at the world, casting doubt on the "possibility of being a man." 62

Through his use of language, Doubrovsky holds, Ionesco truly represents the absurd in more authentic ways than Camus or Sartre did in their theater. Unlike Camus and Sartre, who are conservative because they write coherent characters who speak rationally, Ionesco has launched a "perpetually renewed act of accusation against language" to demonstrate that it has always been a "systematic delirium." Language has been thinking for man, catching him in a false system, rather than man thinking through language. Ionesco's use of puns, meaningless sayings, clichés, and devolution of language into sounds, is actually the disintegration of language. To write the absurd authen-

59. Doubrovsky, "Ionesco and the Comic of Absurdity," 3.

60. Ibid., 6.

61. Ibid., 10.

62. Ibid.

63. Ibid., $8 ; 7$. 
tically, according to Doubrovsky, there must be a disintegration of both the personality of the characters and their language. This new language is invented by the experience of the absurd itself and goes against rational discourse. Rather than the not-yet invented term of theater of the absurd, he calls it a theater of decomposition and a theater of irrationality. The world is a historically situated one, a world of decomposition, as Doubrovsky quotes the character Madeleine in The Alma Impromptu who characterizes the modern world in a "state of decomposition." ${ }^{64}$ Ionesco's use of irrational, disintegrated language reflects the realities of his own postwar moment. Now that Ionesco has destroyed the illusion of language as a means to think, to communicate the truth, the Sartrean experience of nausea truly comes forth and the spectator sees the monstrosity of the world.

Doubrovsky's article represents a complete reversal of Peyre's and Guicharnaud's approach to the absurd. Peyre and Guicharnaud discuss Sartre's and Camus's absurd in terms of the war, showing that anguish and despair are part of the process of taking action. Peyre begins to discuss the role of communication, which Guicharnaud takes up through language as part of his existential awakening after confronting the absurd. Doubrovsky, writing later in the postwar years than his colleagues, instead sees the absurd historic situation as one of decomposition, in which language itself must be shown as disintegrated. The theater of the absurd, or the theater of decomposition, seems to draw out this view in particular. He concludes: "This determination to be gay in face of the utter confusion and final disappearance of all values offers no salvation, it does not conquer absurdity, it stresses it, it does not try to dodge it, it revels in it." ${ }^{165}$ We hear the echo of Camus's famous statement that we must imagine Sisyphus happy, but at the same time Doubrovsky sets up the dichotomy of gayness and revelry on the one hand and utter confusion on the other. For Doubrovsky, Ionesco's decomposed language perfectly replicates this dichotomy. Yet it also marks a departure from action and language in existentialism, and perhaps locates a moment in which the theater of the absurd ceases to be existentialist.

Viewed as a three-part series of reception, these central articles by Peyre, Guicharnaud, and Doubrovsky show a concretization of reading the absurd as one of the central concepts of existentialism, 
62 Yale French Studies

and one that anchors, or even fixes, the idea of the France of World War II as an absurd world. Nevertheless, their depth of interest in this new movement indicates they were certainly not in the business of creating new clichés about existentialism. Rather, they reveal how a moment in time can be read into a movement. By tracing how American understanding of the absurd to this day has been defined through postwar reception of these three scholars-who were Frenchborn and educated but who worked in and introduced the concept to the American academy-new readings of the absurd become possible. 